\title{
PENINGKATAN KEMAMPUAN PEMAHAMAN KONSEP KELILING DAN LUAS BANGUN DATAR PADA SISWA KELAS VII-2 MTSN 28 JAKARTA DENGAN MENGGUNAKAN MEDIA REALIA
}

\author{
Erna Sari Agusta \\ MTsN 28 Jakarta Timur, Indonesia \\ Email:ernasari.agusta@gmail.com
}

\begin{abstract}
This classroom action research answers three questions, namely (a) Is there an increase in the ability to understand the concept of circumference and area of flat shapes by using real media? (b) How is the use of real media increase understanding of circumference and area of flat shapes? The study was conducted in two cycles. Each cycle consists of four stages, namely: design, activity and observation, reflection, and revision. The subject of this research is students of class VII-2 MTsN 28 Jakarta. Data were collected through questionnaires, teacher and student activity questionnaires, formative test, and teaching and learning activity observation sheets. Data were analyzed descriptively using descriptive statistics and qualitative analysis. The results showed that the students' ability to understand the concept of the circumference and area of a flat shape increased from cycle I to cycle II. In the first cycle of meeting 1 (31.6\%), the first cycle of meeting 2 (55.8\%), the second cycle of meeting 1 (71.1\%), the second cycle of meeting 2 (92.1\%). The conclusion of this study is the use of real media can increase understanding and have a positive effect on understanding of circumference and area of flat shapes. The research recommends that teacher can use real to better teaching in the curriculum area.
\end{abstract}

Keywords: action research; circumference and area; real media.

\begin{abstract}
Abstrak
Penelitian tindakan kelas ini menjawab tiga pertanyaan yaitu (a) Apakah terjadi peningkatan kemampuan pemahaman konsep keliling dan luas bangun datar dengan digunakannya alat peraga realita? (b) Bagaimanakah penggunaan alat peraga realita terhadap kemampuan pemahaman konsep keliling dan luas bangun datar?Penelitian dilakukan sebanyak dua siklus. Setiap siklus terdiri dari empat tahap yaitu: rancangan, kegiatan dan pengamatan, refleksi, dan revisi. Sasaran penelitian ini adalah siswa kelas VII-2 MTsN 28 Jakarta. Data dikumpulkan melalui angket pengelolaan kelas, angket aktifitas guru dan siswa, hasil tes formatif, lembar observasi kegiatan belajar mengajar. Data dianalisis secara deskriptif menggunakan statistik deskriptif dan analisis kualitatif. Hasil penelitian menunukkan bahwa kemampuan pemahaman konsep keliling dan luas bangun datar pada siswa mengalami peningkatan dari siklus I sampai siklus II. Pada siklus I Pertemuan 1 (31,6\%), siklus I Pertemuan 2 (55,8\%), siklus II Pertemuan 1 (71,1\%) siklus II Pertemuan 2 (92,1\%). Simpulan dari penelitian ini adalah penggunaan alat peraga dapat meningkatkan dan berpengaruh positif terhadap kemampuan pemahaman konsep keliling dan luas bangun datar. Penelitian ini merekomendasikan agar para guru sebaiknya menggunakan media realia dalam pembelajaran materi tersebut.
\end{abstract}

Kata Kunci: penelitian tindakan; lingkaran dan luas; media realita. 


\section{PENDAHULUAN}

Matematika adalah ilmu yang tidak hanya membahas angka-angka dan operasi bilangan, tetapi ada kemampuan pemahaman konsep yang harus dimiliki siswa agar ia dapat menyelesaikan permasalahan khususnya pada materi keliling dan luas bangun datar. Untuk mempelajari hal-hal yang bersifat terapan, dibutuhkan media dan bendabenda konkret yang dapat memfasilitasi siswa dalam membangun sebuah konsep.

Dalam mempelajari keliling dan luas bangun datar, banyak diantara peserta didik di lingkungan MTsN 28 Jakarta khususnya kelas VII-2 yang sulit memahami konsep keliling dan luas bangun datar. Hal ini disebabkan oleh metode pembelajaran yang lebih kepada hafalan rumus sehingga siswa tidak mengetahui konsep keliling dan luas bangun datar sesungguhnya. Akibatnya siswa tidak mampu untuk menyelesaikan permasalahan yang berkaitan dengan keliling dan luas bangun datar, Aktivitas belajar siswa pun cenderung pasif. Hal ini dapat dilihat dari kurang terlibatnya mereka dalam mengerjakan soal yang diberikan oleh guru saat KBM berlangsung. Berdasarkan nilai ulangan harian diketahui, dari 38 siswa hanya sekitar 25,64\% siswa yang mendapat nilai sama dengan atau di atas KKM (> 68).

Berdasarkan hasil tes pra penelitian diketahui, 50\% siswa belum menguasai materi garis dan sudut. Banyak diantara mereka yang belum memahami konsep titik, garis, dan bidang sebagai penyusun/unsur- unsur yang terdapat dalam bangun datar. Setelah dilakukan refleksi, guru hanya menjelaskan bangun datar secara lisan ditambah dengan menuliskan rumus-rumus yang terkait di dalamnya. Berdasarkan hasil pengamatan, terlihat pula minimnya guru dalam menggunakan alat peraga dalam menyampaikan informasi bangun datar kepada siswa.

Kebutuhan alat peraga sebagai media untuk memahami konsep tentu selaras dengan tuntutan kurikulum 2013 dimana siswa tidak hanya menguasai aspek pengetahuan tetapi sampai pada aspek keterampilan. Penggunaan alat peraga akan membuat pembelajaran menjadi bermakna karena peserta didik diajak untuk terlibat langsung dalam proses pembelajaran.

Kemampuan pemahaman konsep adalah kompetensi dalam menjelaskan keterkaitan antar konsep dan mengaplikasikan konsep atau algoritma secara luwes, efisien, akurat dan tepat dalam pemecahan masalah. Pemahaman konsep dalam Permendikbud (2014) dapat dilihat dari kemampuan siswa dalam: (1) menyatakan ulang konsep yang telah dipelajari, (2) mengklasifikasikan objekobjek berdasarkan dipenuhi tidaknya persyaratan yang membentuk konsep tersebut, (3) mengidentifikasi sifat-sifat operasi atau konsep, (4) menerapkan konsep secara logis, (5) memberikan contoh atau contoh kontra (bukan contoh) dari konsep yang dipelajari, (6) menyajikan konsep dalam berbagai macam bentuk representasi matematis (tabel, grafik, diagram, gambar, sketsa, model matematika, atau cara lainnya), 


\section{Wawasan}

Jurnal Balai Diklat Keagamaan Jakarta

P.ISSN 2548-9232; E-ISSN 2775-3573

Volume 1 Nomor 2 Tahun 2020:

mengaitkan berbagai konsep dalam matematika maupun di luar matematika, dan (8) mengembangkan syarat perlu dan atau syarat cukup suatu konsep. Berdasarkan definisi di atas dapat dikatakan bahwa kemampuan pemahaman konsep adalah kemampuan untuk menyatakan kembali suatu konsep, mengklasifikasikan, mengidentifkasikan dan menerapkan suatu konsep serta mengaitkannya dengan konsep lainnya.

Menurut Iswaji alat peraga adalah seperangkat benda konkret yang dirancang, dibuat, dihimpun, dan disusun secara sengaja yang digunakan untuk membantu menanamkan dan mengembangkan konsep-konsep pada mata pelajaran tertentu (Iswaji, 2003). Menurut Sudjana alat peraga adalah suatu alat yang dapat diserap oleh mata dan telinga dengan tujuan membantu guru agar proses belajar mengajar siswa lebih efektif dan efisien (Sudjana \& Rivai, 2001). Menurut Qurtubi alat peraga adalah benda yang dapat diamati dimana pengamatan tersebut menimbulkan pengertian, selanjutnya pengertian yang satu menimbulkan pengertian berikutnya sehingga bergabung menjadi sebuah pengetahuan (Qurtubi, 2009).

Berdasarkan beberapa definisi diatas dapat dikatakan bahwa alat peraga adalah sebuah alat yang sengaja dibuat dimana alat tersebut dapat diserap oleh mata dan telinga sehingga menimbulkan pengertian yang membangun sebuah pengetahuan.

Alat peraga dalam pembelajaran matematika membantu menyajikan konsep-konsep matematika menjadi kongkrit. Karakter alat peraga aeperti itu membantu peserta didik dalam lebih mudah memahami konsep matematika. Rochmad menyatakan bahwa menanamkan konsep matematika dengan menggunakan alat peraga menyebabkan pengalaman anak semakin luas karena berdasarkan sesuatu yang nyata (Priambodo, Sugiarto, \& Cahyono, 2014). Selain itu. Sugiharto mengungkapkan juga bahwa dalam proses materi pelajaran yang bersifat konsep, matematika sebaiknya siswa diberi kesempatan untuk memanipulasi benda-benda konkret atau alat peraga yang dirancang secara khusus dan dapat diotak-atik oleh siswa dalam memahami suatu konsep matematika (Pujiati \& Mastur, 2014). Sedangkan menurut Suherman belajar dengan menggunakan alat peraga membuat proses belajar mengajar akan lebih aktif dimana siswa akan senang, terangsang, dan tertarik dalam belajar (Suherman, 2001).

Berdasarkan beberapa pendapat di atas dapt disimpulkan bahwa penggunaan alat peraga dapat membangkitkan keinginan siswa untuk belajar karena dapat lebih mudah memahami konsep abstrak matematika melalui bentuk konkret. Selanjutnya kemampuan pemahaman konsep mempunyai keterkaitan, dimana alat peraga dapat membantu siswa dalam menanamkan konsep, khususnya dalam menentukan keliling dan luas bangun datar. Alat peraga juga mampu menjelaskan konsep titik, garis, dan bidang yang akan membangun pemahaman siswa 


\section{Wawasan}

Jurnal Balai Diklat Keagamaan Jakarta

p.ISSN 2548-9232; E-ISSN 2775-3573

Volume 1 Nomor 2 Tahun 2020:

tentang konsep keliling dan luas bangun datar.

$$
\text { Berdasarkan hasil penelitian }
$$
dijelaskan bahwa penggunaan alat peraga dapat meningkatkan kemampuan pemahaman konsep dan keaktifan siswa dalam materi peluang (Setyowati, Susilo, \& Masrukan, 2016). Penelitian dalam area yang samamenunjukkan bahwa penggunaan alat peraga mempunyai pegaruh yang signifikan terhadap kemampuan pemahaman konsep matematis siswa (Suwardi, Firmiana, \& Rohayati, 2014).

Berdasarkan penjelasan teoretis di atas peneliti tertarik untuk melakukan sebuah penelitian tindakan untuk penerapan media peraga realia untuk membentu peserta didik memahami konsep keliling dan luas pada peserta didik kelas VII dengan rumusan masalah berikut: Apakah penggunaan alat peraga dapat meningkatkan kemampuan pemahaman konsep keliling dan luas bangun datar pada siswa MTsN 28 jakarta?

Penelitian ini bertujuan untuk meningkatkan kemampuan pemahaman konsep keliling dan luas bangun datar dan menjelaskan cara penggunaan alat peraga untuk meningkatkan kemampuan pemahaman konsep tersebut. Adapun manfaat penelitian ini adalah meningkatnya kemampuan pemahaman konsep keliling dan luas bangun datar pada siswa. Selain itu, sebagai bahan referensi dan rujukan bagi dewan guru khususnya di MTsN 28 dalam memperkaya ide dan kreativitas dalam penggunaan alat peraga. Dengan hasil belajar yang lebih baik maka diharapkan dapat meningkatkan kualitas output sekarang dan yang akan datang.

\section{METODE}

Penelitian ini adalah penelitian tindakan kelas (action research) yang dilakukan pada siswa kelas VII-2 di MTsN 28 dengan jumlah siswa 38 orang. Adapun waktu penelitian mulai dari pemberian tes pra penelitian hingga penyusunan laporan berlangsung selama 3 bulan mulai Maret hingga Mei 2020.

Materi yang dibahas dalam penelitian ini adalah keliling dan luas bangun datar yang meliputi persegi panjang, persegi, jajargenjang, belah ketupat, jajargenjang, dan trapesium. Pembelajaran dilakukan dengan menggunakan alat peraga berupa model-model bangun datar dan jaringjaringnya, baik yang terbuat dari karton maupun kayu. Pembelajaran didesain dengan sistem belajar kelompok yang terdiri dari 4 orang.

Model penelitian tindakan yang digunakan adalah model Kemmis Mc Taggart. Dalam model penelitian tindakan tersebut satu siklus penelitian terdiri dari empat tahap uaitu Planning (perencanaan), acting (tindakan), observing (pengamatan) dan reflecting (refleksi) (Suryadi \& Berdiati, 2018).

Penelitian ini dilaksanakan dalam 2 siklus. Adapun kegiatan tiap siklusnya dimulai dengan mengadakan pertemuan guru pelaksana tindakan dan guru pengamat untuk mendiskusikan persiapan penelitian sampai penyusunan rencana pembelajaran soal tes, pedoman wawancara, lembar observasi dan catatan lapangan.

Pada tahap pelaksanaan tindakan, guru matematika kelas VII-2 sebagai pelaksana tindakan 
Wawasan

Jurnal Balai Diklat Keagamaan Jakarta

p.ISSN 2548-9232; E-ISSN 2775-3573

Volume 1 Nomor 2 Tahun 2020:

melaksanakan kegiatan pembelajaran sesuai dengan rencana pembelajaran yang telah disusun. Untuk mengukur kemampuan pemahaman konsep siswa menggunakan tes dan untuk mengetahui aktivitas siswa dalam pembelajaran menggunakan angket respon siswa. Pada tahap refleksi, data yang diperoleh dari hasil evaluasi kemudian dianalisis. Hasil analisis digunakan untuk merefleksi tindakan pada siklus tersebut. Hasil refleksi kemudian digunakan untuk membuat perencanaan tindakan pada siklus berikutnya.

Indikator keberhasilan penelitian ini jika terlihat peningkatan kemampuan pemecahan masalah pada materi keliling dan luas bangun datar. Hal ini ditunjukkan dengan adanya peningkatan jumlah siswa yang mencapai KKM 75 dan mengalami ketuntasan belajar sebesar $75 \%$ secara klasikal. Siklus kan dihentikan jika indicator keberhasilan sudah mengalami peningkatan dai siklus I ke siklus II.

\section{HASIL DAN PEMBAHASAN}

Hasil tes pra penelitian yang diberikan sebelum melakukan penelitian menunjukkan bahwa penguasaan konsep siswa pada materi prasyarat bangun datar masih kurang yaitu hanya $50 \%$. Oleh karena itu, perlu dilakukan pengulangan materi prasyarat, sekaligus penjelasan dan sosialisasi tentang apa, bagaimana, dan tujuan penggunaan alat peraga dalam pembelajaran yang akan dilakukan.

$$
\text { Pada proses pelaksanaan }
$$
pembelajaran dengan menggunakan alat peraga dilakukan pengamatan aktifitas belajar peserta didik pada stia silkus. Hasil pengamatan diperoleh data pada tabel 1.
Tabel 1 Rekap HAsil Pengamatan

\begin{tabular}{|c|c|c|c|}
\hline $\begin{array}{l}\mathbf{N} \\
\mathbf{O}\end{array}$ & PERNYATAAN & $\begin{array}{l}\text { Siklus } \\
\text { I }\end{array}$ & $\begin{array}{l}\text { Siklus } \\
\text { II }\end{array}$ \\
\hline 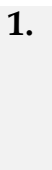 & $\begin{array}{l}\text { Menyatakan } \\
\text { ulang konsep } \\
\text { yang telah } \\
\text { dipelajari }\end{array}$ & $\begin{array}{c}16 \\
(42,1 \% \\
\quad)\end{array}$ & $\begin{array}{c}32 \\
(84,2 \%)\end{array}$ \\
\hline 2. & $\begin{array}{l}\text { Mengklasifikasika } \\
\text { objek-objek } \\
\text { berdasarkan } \\
\text { dipenuhi tidaknya } \\
\text { persyaratan yang } \\
\text { membentuk } \\
\text { konsep tersebut }\end{array}$ & $\begin{array}{c}15 \\
(39,5 \%)\end{array}$ & $\begin{array}{c}32 \\
(84,2 \%)\end{array}$ \\
\hline 3. & $\begin{array}{l}\text { Mengidentifikasi } \\
\text { sifat-sifat operasi } \\
\text { atau konsep }\end{array}$ & $\begin{array}{c}13 \\
(34,2 \%)\end{array}$ & $\begin{array}{c}30 \\
(78,9 \%)\end{array}$ \\
\hline 4. & $\begin{array}{l}\text { Menerapkan } \\
\text { konsep secara logis }\end{array}$ & $\begin{array}{c}13 \\
(34,2 \%)\end{array}$ & $\begin{array}{c}30 \\
(78,9 \%\end{array}$ \\
\hline
\end{tabular}

5. Memberikan

$13 \quad 28$

contoh-atau contoh $(34,2 \%) \quad(73,7 \%)$

kontra (bukan

contoh) dari konsep

yang dipelajari

6. Menyajikan

konsep dalam

berbagai macam

bentuk

representasi

matematis (tabel,

grafik, diagram,

gambar, sketsa,

model

matematika, atau

cara lainnya)

7. Mengaitkan

$10 \quad 29$

$(26,3 \%) \quad(76,3 \%)$

berbagai konsep

dalam matematika

maupun di luar

Matematika

8. Mengembangkan syarat perlu dan atau syarat cukup suatu konsep

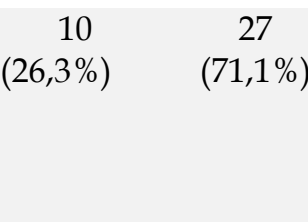

10

$(26,3 \%)$

27

$(71,1 \%)$
Pada siklus I pertemuan 1, diketahui hanya ada 10 orang yang terlihat sangat beraktivitas dan terlibat dalam pembelajaran atau sebesar $26,3 \%$. Mereka adalah siswa yang selalu antusias dalam belajar apapun 
materi yang dipelajari. Sedangkan siswa lainnya masih terlihat bingung. Lembar Kerja Siswa (LKS) pun masih banyak yang terlihat kosong. Pada siklus ini, siswa masih banyak bertanya kepada guru daripada mencoba menggunakan alat peraga. Dalam hal ini, guru berusaha mengarahkan siswa agar dapat menemukan konsep keliling bangun datar sesuai dengan soal yang terdapat dalam LKS dengan bantuan alat peraga.

Pada siklus I pertemuan 2, mulai terlihat penambahan jumlah siswa yang aktif dan berkontribusi dalam penemuan konsep keliling bangun datar naik menjadi 14 orang atau sekitar $43,8 \%$. Komunikasi antar peserta didik pun dilakukan tidak hanya antar anggota dalam satu kelompok, tetapi juga antar anggota dari kelompok yang berbeda. Konsep keliling ditemukan dengan melakukan pengukuran seluruh sisi model bangun datar lalu dikaitkan dengan panjang masing-masing sisinya. Leo (dalam Margiyati dan Halidjah, (2013) mengatakan bahwa alat peraga berupa model bangun datar dapat meningkatkan aktivitas fisik, mental, dan emosional siswa. Selain itu, pembelajaran dengan alat peraga model bangun datar dapat meningkatkan kemampuan pemahaman konsep siswa. Pada akhir siklus I, siswa diberikan tes untuk mengurkur peningkatan hasil belajar. mengukur kemampuan pemahaman konsep keliling bangun datar.

Selanjutnya pada siklus II pertemuan 1, jumlah siswa yang aktif dalam pembelajaran menunjukkan peningkatan hingga 2,5\%. Sebanyak 20 orang siswa mampu untuk menjawab soal terkait konsep luas bangun datar yang terdapat pada Lembar Kerja Siswa dengan menggunakan alat peraga. Chotamah (Lestiana \& Kurniasih, 2016) mengatakan bahwa pembelajaran matematika dengan alat peraga bangun datar dapat meningkatkan keaktifan siswa, menimbulkan pengalaman baru yang menyenangkan, menimbulkan rasa demokratif, inovatif, dan kreativitas. Konsep luas dapat ditemukan antara lain dengan menutup permukaan model bangun datar dengan kertas berpetak. Siswa menghitung banyak kotak kertas berpetak yang menutupi permukaan bangun datar, lalu mengaitkan dengan sisi, alas, tinggi, atau diagonal dari bangun datar tersebut.

Bangun datar yang paling mudah dipahami siswa adalah persegi panjang. Karenanya ada siswa yang menemukan konsep luas bangun datar lainnya dengan menganalogikan bentuk bangun datar lainnya menjadi bentuk persegi panjang hingga ditemukan konsep luas bangun datar tersebut. Hal ini dilakukan siswa dengan memotong, lalu menempel bagian-bagian bangun datar tersebut hingga terbentuk bangun persegi panjang. Berdasarkan pengamatan, jumlah siswa yang aktif bekerja mengisi Lembar Kerja Siswa dalam kelompok pun mulai bertambah. Pada akhir pembelajaran, siswa diberikan tes untuk mengukur kemampuan pemecahan masalah.

Pada siklus II pertemuan 1, aktivitas siswa diisi dengan presentasi. Perwakilan setiap kelompok memaparksn jawaban Lembar Kerja Siswa yang telah mereka kerjakan. Sedangkan anggota kelompok lainnya membantu memberikan jawaban atau sanggahan dari kelompok lain. Berdasarkan pengamatan, 20 siswa sudah mampu menjawab pertanyaan guru dan menjelaskan kosep keliling dan luas bengun datar. Diskusi kelompok pun berjalan dengan baik. Hal ini disebabkan oleh komposisi kelompok yang heterogen dan merata, dimana siswa yang lebih pintar 


\section{Wawasan}

Jurnal Balai Diklat Keagamaan Jakarta

P.ISSN 2548-9232; E-ISSN 2775-3573

Volume 1 Nomor 2 Tahun 2020:

membantu temannya yang agak lambat dalam pembelajaran.

Pada siklus II pertemuan 2, antusias siswa dalam menjawab dan tampil ke depan kelas baik dalam presentasi maupun dalam memberikan penjelasan terkait luas bangun datar pun semakin meningkat. Berdasarkan pengamatan, 30 orang siswa sudah dapat memberikan kontribusi dalam berdiskusi dan terlibat dalam menyampaikan ide, pendapat dan gagasan terkait dengan luas bangun datar. Hal ini dibuktikan pula dengan kemampuan siswa menjawab benar pertanyaan guru tentang konsep keliling dan luas bangun datar kepada siswa sebagai feedback dari pelaksanaan pembelajaran pada siklus ini.Selain aktivitas, penggunaan alat peraga memiliki dampak positif dalam meningkatkan kemampuan pemahaman konsep keliling dan luas siswa. Hal ini dapat dilihat dari bertambahnya jumlah siswa yang menguasai indikator kemampuan. Pada awal siklus, siswa sudah dapat menyatakan ulang sebuah konsep keliling dan luas bangun datar dengan menggunakan alat peraga. Kemudian siswa diarahkan untuk mengklasifikasikan berbagai macam bentuk bangun datar berdasarkan dipenuhi tidaknya persyaratan yang membentuk konsep tersebut. Kemampuan ini baru dikuasai oleh 42,1\% dari jumlah siswa seluruhnya.

Dengan menggunakan alat peraga, siswa mencoba mengidentifikasi sifatsifat atau konsep bangun datar dan menerapkan konsep tersebut secara logis dalam penyelesaian masalah.. Sedangkan untuk meyakinkan siswa bahwa mereka memang telah memahami konsep, maka mereka diminta untuk memberikan contoh dan bukan contoh dari konsep luas dan keliling bangun datar yang telah dipelajari. Dalam hali ini kemampuan siswa sudah sampai pada menemukan konsep keliling persegi panjang.

Namun, untuk menyajikan konsep dalam berbagai macam bentuk representasi matematis (tabel, grafik, diagram, gambar, sketsa, model matematika, atau cara lainnya), mengaitkan berbagai konsep dalam matematika maupun diluar matematika, serta mengembangkan syarat perlu dan syarat cukup suatu konsep masih sangat kurang. Dalam hal ini kemampuan siswa sudah menemukan konsep luas persegi panjang dari dua buah segitiga siku- siku, konsep luas jajargenjang dari dua buah segitiga lancip, konsep luas trapesium siku-siku yang terdiri dari persegi panjang dan segitiga siku-siku.

Selain itu, alat peraga ketuntasan belajar pun meningkat secara klasikal dari siklus I sampai siklus II. Berikut adalah tabel rekapitulasi hasil belajar matematika siswa:

Tabel 2 Rekap Skor Hasil Tes

\begin{tabular}{l|c|c|c|c}
\multicolumn{4}{c}{} & \multicolumn{4}{c}{ HASIL BELAJAR SISWA } \\
\cline { 2 - 5 } KATEGORI & Siklus & Siklus & Siklus & Siklus \\
& I/1 & I/2 & II/1 & II/2 \\
NILAI & & & & \\
RATA- & 43,0 & 59,3 & 73,6 & $\mathbf{7 5 , 8}$ \\
RATA & 7 & 4 & 8 & \\
JUMLAH & 1 & 2 & 2 & $\mathbf{3}$ \\
KETUNT & 6 & 2 & 7 & $\mathbf{1}$ \\
PERSENT & $\mathbf{4 2 , 1}$ & $\mathbf{5 7 , 9}$ & $\mathbf{7 1 , 0}$ & $\mathbf{7 8 , 1}$ \\
ASE & $\%$ & $\mathbf{0}$ & $\%$ & $\mathbf{0}$ \\
& & & &
\end{tabular}

Berdasarkan tabel diatas dapat dikatakan bahwa dengan menggunakan alat peraga, ketuntasan belajar baik secara individu maupun klasikal mengalami peningkatan dari siklus I ke siklus II. Hal ini dapat dilihat dari peningkatan nilai rata-rata dan prosentase ketuntasan yang sudah mencapai $78,1 \%$. Adapun faktor yang menghambat ketercapaian nilai KKM 
siswa pada umumnya bukan disebabkan

Volume 1 Nomor 2 Tahun 2020:

oleh ketidakpahaman terhadap konsep, melainkan rendahnya kemampuan kemampuan berhitung dari tiap siswa itu sendiri.

\section{KESIMPULAN}

Melalui Penggunaan alat peraga membantu relia peserta didik dalam meningkatkan kemampuan pemahaman konsep keliling dan luas bangun datar. Penggunaan alat peraga juga memiliki dampak positif dalam meningkatkan aktivitas belajar siswa. Terjadi peningkatan terhadap hasil belajar konsep keliling dan luas pada masingmasing siklus. Pada siklus pertama ratarata 51.21 atau $50 \%$ dan meningkat menjadi 74.74 atau $74.75 \%$. 


\section{DAFTAR PUSTAKA}

Iswaji, D. (2003). Pengembanga Media/Alat Peraga Pembelajaran Matematikan di SLTP. Jakarta.

Lestiana, L., \& Kurniasih, R. (2016). Alat Peraga Konsep Luas Bangun Datar. Seminar Nasional Matematika. Jakarta: PRISMA.

Priambodo, A., Sugiarto, S., \& Cahyono, A. (2014). Keefektifan Model Cicle Berbantuan Alat Peraga Terhadap Kemampuan Komunikasi Matematis. Journal of Mathematics Education.

Pujiati, I., \& Mastur, Z. (2014). KEEFEKTIFAN MODEL POGIL BERBANTUAN ALAT PERAGA BERBASIS ETNOMATEMATIKA TERHADAP KEMAMPUAN KOMUNIKASI MATEMATIS. INNES Journal ogf Mathematics Education, 174-180.

Qurtubi, H. (2009). Teknologi dan Media Pendidikan. Jakarta: PT. BIntang Harapan Sejahtera.

Setyowati, N., Susilo, B., \& Masrukan, M. (2016). Penggunaan Alat Peraga untuk Meningkatkan Hasil Belajar dan Keaktifan Siswa Mata Diklat Matematika Materi Peluang di Kelas X AP B Smester Genap SMKN 1 Bawean. Kreano, Jurnal Matematika Kreatif-Inovatif.

Sudjana, N., \& Rivai, A. (2001). Media Pembelajaran. Bandung: Sinar Baru Algensindo.

Suherman, E. (2001). Strategi Pembelajaran Matematika Kontomporer. Bandung: JICA Universitas Pendidikan Indonesia.

Suryadi, A., \& Berdiati, I. (2018). Menggagas Penelitian Tindakan Kelas untuk Guru. Bandung: Remaja Rosda Karya.

Suwardi, S., Firmiana, M. E., \& Rohayati, R. (2014). Pengaruh Penggunaan Alat Peraga terhadap Hasil Pembelajaran Matematika pada Anak Usia Dini. Jurnal Al-Azhar Indonesia. 